\title{
The effect of intermittent feeding and cold water on performance and carcass traits of broilers reared under daily heat stress
}

\author{
Kadir Erensoy ${ }^{1, *}$, Moise Noubandiguim ${ }^{2,3}$, Musa Sarıca', and Resul Aslan ${ }^{1}$
}

* Corresponding Author: Kadir Erensoy Tel: +90-362-312-19-19-1442, Fax: +90-362-457-60-34,

E-mail: kadir.erensoy@omu.edu.tr

${ }^{1}$ Department of Animal Science, Agricultural Faculty, Ondokuz Mayis University, 55139 Samsun, Turkey

2 Department of Biology, Faculty of Art and Sciences, Ondokuz Mayis University, 55139 Samsun, Turkey

${ }^{3}$ National High Institute of Sciences and Techniques, Institut National Supérieur des Sciences et

Techniques d'Abéché (INSTA), 40823 Abeche, Tchad

ORCID

Kadir Erensoy

https://orcid.org/0000-0002-7479-6203

Moise Noubandiguim

https://orcid.org/0000-0003-0734-8600

Musa Sarica

https://orcid.org/0000-0001-5331-0596

Resul Aslan

https://orcid.org/0000-0001-6672-3541

Submitted Dec 10, 2019; Revised Jan 15, 2020; Accepted Mar 3, 2020
Objective: This study aimed to determine the effect of intermittent feeding and cold water on performance and carcass traits in broiler chickens between 4 to $6 \mathrm{wk}$ of age exposed to daily high temperature.

Methods: Broilers were assigned to four treatment groups according to a $2 \times 2$ factorial design between 22 to $42 \mathrm{~d}$ of age ( 80 broilers per treatment, 4 replications). Broilers were divided into two main groups as feeding type (ad-libitum [AL] and intermittent [IF] for $6 \mathrm{~h}$ daily) and sub-groups as water temperature (normal [NW], $24.9^{\circ} \mathrm{C}$ and cold $[\mathrm{CW}], 16.4^{\circ} \mathrm{C}$ ). Heat treatment was applied between 11.00 to $17.00 \mathrm{~h}$ daily between 22 to $42 \mathrm{~d}$ of age.

Results: Live weight at 6th wk was not affected by feeding type and water temperature, but the live weight was significantly higher in IF chickens at the 5 th wk $(\mathrm{p}<0.05)$. Average weekly gain of IF broiler chickens were higher compared to AL group at 4, 5, and 6 wk of age ( $\mathrm{p}<$ 0.05 ). Although feeding type did not affect feed intake in 4 and 5th wk, feed intake was higher in IF chickens at 6th wk $(\mathrm{p}<0.01)$. In addition, feeding type and water temperature did not affect feed conversion ratio and interactions were not significant $(p>0.05)$. Water temperature had no significant effect on heart, liver, gizzard, and abdominal fat percentages ( $>>0.05)$.

Conclusion: It is concluded that IF increased the average weekly gain in chickens reared under daily heat stress for $6 \mathrm{~h}$ between 22 to $42 \mathrm{~d}$ of age. IF in hot environmental conditions slightly increased performance without adversely affecting health, welfare, and physiological traits, whereas CW implementation had no significant effect on performance. It can also be said that IF suppresses a sudden increase in body temperature depending on age and live weight.

Keywords: Broiler; Intermittent Feeding; Cold Water; Feed Conversion; Water Intake

\section{INTRODUCTION}

High environmental temperatures can cause significant problems in broiler production, especially during summer months. The optimum ambient temperature for poultry is also called thermal neutral zone $\left(18^{\circ} \mathrm{C}\right.$ to $\left.24^{\circ} \mathrm{C}\right)$ and the values above are considered as temperature stress [1]. As the ambient temperature increases, the difference between body temperature decreases and sensible heat loss becomes more difficult [2]. While poultry struggle with high temperature, they also try to keep body temperature within physiological limits by increasing body surface area and respiration rate as well as reducing feed intake and activity [3]. Heat stress causes various harmful effects on physiological, immune, welfare, health, performance and meat quality traits and results in serious economic losses by making internal heat dissipation difficult in poultry [4]. Numerous studies have been carried out to maintain feed efficiency and product quality by reducing body heat production and providing better internal heat dissipation. Genetically developing broiler chickens with featherless 
neck gene [5], changing feed content [6], limited feeding and lighting programs [7], intermittent feeding (IF) implementation in hot hours [8] and cold water (CW) applications [9] have been reported to reduce metabolic heat production. It has been stated that a daily fasting period of 6 to 8 hours for broiler chickens subjected to heat stress can reduce the fat reserves and provide a profitable production without affecting the mortality rate $[10,11]$.

Water consumption increases at high ambient temperatures [12], but the rise in water temperature also adversely affects performance [13]. It has been reported that as the difference between the temperature of the consumed water and body temperature increases, heat dissipation becomes easier and $\mathrm{CW}$ intake improves performance under heat stress conditions [14]. Sudden temperature changes may occur in summer months, especially in non-environmentally controlled houses. During these periods, also depending on the relative humidity, it is not possible to cool by using air velocity, and high mortality rates may occur and decrease the overall performance [15]. The adverse effects of temperature increase on broiler chickens are more pronounced in the second half of the production period (4 to $6 \mathrm{wk}$ ), when growth rate and live weight gain are high. This study aimed to determine the effect of IF and CW on performance and carcass traits in broilers between 22 to $42 \mathrm{~d}$ of age subjected to daily high temperature.

\section{MATERIALS AND METHODS}

\section{Chicken and housing material}

This study was conducted at Ondokuz Mayis University, Agricultural Faculty experimental farm in June-July 2019. All procedures were approved by Ondokuz Mayis University Ethical Committee for Experimental Animals (30.06.2017; 2017/31).

All eggs were collected and transferred to the hatchery on the same day. After $21 \mathrm{~d}$ incubation period, 320 day-old chicks of "Anadolu-T" were randomly selected and used for the experiment. The chicks were reared on $8 \mathrm{~cm}$-thick wood shavings litter to by the end of 3 th wk with feed and water continuously available during the experimental period ( 22 to $42 \mathrm{~d}$ ). Birds were housed in windowed, artificially lighted and ventilated house containing heaters producing hot air automatically. Unit sizes were $1.00 \times 1.50 \mathrm{~m}$, containing one $15 \mathrm{~kg}$ capacity tube feeder and 2 nipple drinkers per pen. Economical white bulbs were used for lighting. In order to avoid any effect of intermittent lighting, continuous $24 \mathrm{~h}$ lighting was applied during experiment. All chicks were fed ad-libitum until the end of the third wk. Water was also given ad-libitum during the whole experiment period. The feeds were obtained from a commercial firm and nutritional content of feeds are given in Table 1.

\section{Experimental design}

A total of 320 broiler chickens at the age of 21 days was randomly divided into 4 experimental groups in a $2 \times 2$ factorial design that included 2 feeding systems (AL, ad libitum; IF, intermittent feeding) and 2 systems of water temperature (NW, normal water; and CW). Feed was provided continuously to AL group for $24 \mathrm{~h}$. The IF group was fasted for $6 \mathrm{~h}$ between 11.00 and 17.00 until end of the study. Between these hours, the feeders were taken to a height of about $1 \mathrm{~m}$ that chickens could not reach. At the end of this period, the feeders were lowered to the broiler level until the next day fasting period.

In the water temperature treatment, tap water was used for the normal temperature group for $24 \mathrm{~h}$ and average of water temperature was $24.9^{\circ} \mathrm{C}$ during the study. In $\mathrm{CW}$ application, the water temperature was kept between $14^{\circ} \mathrm{C}$ to $18^{\circ} \mathrm{C}$ with the help of cool-packs for $24 \mathrm{~h}$ and the average temperature of water provided was $16.4^{\circ} \mathrm{C}$.

The light intensity was 20 to 25 lux in the all chicken pens. At least $33^{\circ} \mathrm{C}$ to $34^{\circ} \mathrm{C}$ temperature was provided in the house for the first $3 \mathrm{~d}$ and it was gradually decreased by $2^{\circ} \mathrm{C}$ to $2.5^{\circ} \mathrm{C}$ per week until $21 \mathrm{~d}$ of age. Heat treatment was applied between 11.00 and $17.00 \mathrm{~h}$ daily from the beginning of the 4 th week to the slaughter age. Actual environmental conditions are given in Table 2 .

\section{Data collection}

At the end of the 3th wk, all chickens were tagged with a num-

Table 1. Nutritional content of feeds used in the study

\begin{tabular}{lcccc}
\hline Nutrients & $\begin{array}{c}\text { Starter } \\
(\mathbf{1} \text { to } \mathbf{~ d})\end{array}$ & $\begin{array}{c}\text { Grower } \\
(\mathbf{8} \text { to } \mathbf{2 8} \mathbf{d})\end{array}$ & $\begin{array}{c}\text { Grower 2 } \\
\text { (29 to 35 d) }\end{array}$ & $\begin{array}{c}\text { Finisher } \\
(\mathbf{3 6} \text { to 42 d) }\end{array}$ \\
\hline Crude protein (\%) & 23.00 & 22.00 & 21.00 & 18.00 \\
Metabolizable energy (kcal/kg) & 3,000 & 3,100 & 3,100 & 3,100 \\
Crude cellulose (\%) & 4.00 & 4.00 & 4.00 & 6.00 \\
Crude ash (\%) & 5.00 & 5.00 & 5.00 & 5.00 \\
Ca (\%) & 1.00 & 0.95 & 0.80 & 0.80 \\
Phosphorus (\%) & 0.50 & 0.50 & 0.45 & 0.60 \\
Methionine (\%) & 1.00 & 0.45 & 0.40 & 0.40 \\
Lysine (\%) & 1.35 & 1.20 & 1.10 & 1.00 \\
\hline
\end{tabular}


Table 2. Temperature and relative humidity levels of the poultry house during 4 to 6 weeks

\begin{tabular}{|c|c|c|c|c|}
\hline \multirow[b]{2}{*}{ Weeks } & \multicolumn{2}{|c|}{ Temperature $\left({ }^{\circ} \mathrm{C}\right)$} & \multicolumn{2}{|c|}{ Relative humidity (\%) } \\
\hline & $\begin{array}{c}\text { Treatment } \\
(11.00-17.00 \mathrm{~h})\end{array}$ & $\begin{array}{c}\text { Normal } \\
(18.00-10.00 \mathrm{~h})\end{array}$ & $\begin{array}{c}\text { Treatment } \\
(11.00-17.00 \mathrm{~h})\end{array}$ & $\begin{array}{c}\text { Normal } \\
(18.00-10.00 \mathrm{~h})\end{array}$ \\
\hline 4th & 29.4 & 24.5 & 62.8 & 71.8 \\
\hline 5th & 29.8 & 25.2 & 61.8 & 70.8 \\
\hline 6 th & 30.8 & 26.1 & 59.6 & 68.1 \\
\hline Mean & 30.0 & 25.3 & 61.4 & 70.2 \\
\hline
\end{tabular}

bered wing band, individual live weights were taken and 10 males and 10 females were randomly distributed in each pen. The live weight, feed intake and water intake were measured every week at the same time, and the average daily weight gain between each pair of consecutive live weight measurements was calculated for each chick in every weekly interval. A scale with $1 \mathrm{~g}$ precision (Jadever, JWQ-6 Digital Precision Scale, Northspring BizHub Industrial Building, Singapore) was used in determination of live weight and feed intake. Water intake was determined by reading the scale on the bucket nipple drinkers located in each pen separately. A 10-liter bucket with 2 nipple drinkers was used as a drinker system per a pen. The amount of water remaining in the drinkers was determined by the scale on the bucket at 9 a.m. every morning and net water intake per chicken was calculated weekly. Mortality was determined daily and weighed in order to calculate the adjusted feed conversion ratio (FCR, $\mathrm{kg}$ of feed consumed $/ \mathrm{kg}$ of body weight). The water temperature was measured 4 times a day (at 9.00, 13.00, 17.00, and 22.00) with a $0.1^{\circ} \mathrm{C}$ precision liquid thermometer.

The rectal temperature was measured with a manual electronic thermometer $\left( \pm 0.1^{\circ} \mathrm{C}\right)$ by inserting into the rectum 2 to $3 \mathrm{~cm}$ in depth for each bird. It was carried out twice a week at 14.00 in order to determine the relationship between heat stress and feeding type and water temperature. Each measurement was taken from 8 males and 8 females from each group (64 chickens in total). During the measurement period (30 s) the chicken was gently handled. In the evaluation of the data, the average of the values taken from male and female was used. Dataloggers (Testo 174H, West Chester, PA, USA) were used for monitoring and determination of the house temperature and humidity values every 15 minutes.

Two males and two females close to the mean body weight were selected randomly from each pen and slaughtered after an $8 \mathrm{~h}$ fasting period at $42 \mathrm{~d}$ of age. Birds were individually weighed and slaughtered by cervical dislocation. Semi-automated equipment was used for scalding $\left(1 \mathrm{~min}\right.$ at $\left.56^{\circ} \mathrm{C}\right)$, plucking, chilling (in $\mathrm{CW}, 5 \mathrm{~min}$ at $1^{\circ} \mathrm{C}$ to $5^{\circ} \mathrm{C}$ ), vent-opening, evisceration, and air-chilling $\left(12 \mathrm{~h}\right.$ at $\left.4^{\circ} \mathrm{C}\right)$. Following airchilling, abdominal fat was evaluated and recorded as the ratio of fat surrounding abdominal muscles, cloaca and inner organs to live weight. Carcasses were cut into parts according to standard methods, and thigh, breast, neck, wings, back, edible inner organs (heart, liver, and gizzard) and abdominal fat weights were determined. Carcass, edible inner organ and abdominal fat percentages recorded as percentages of cold-carcass weights, and also abdominal fat ratio was calculated by the slaughter weight [16].

\section{Statistical analysis}

The study was designed with a completely randomized design and a $2 \times 2$ factorial arrangement (feeding type $\times$ water temperature) with 4 replicates. The data were normally distributed and were subjected to statistical analysis using the general linear model of the SPSS (Version 25.0) program. Statistical analyses were used to determine the effects of feeding type, water temperature and the interactions of these factors on broiler chickens performance and carcass traits. Since the interactions are not statistically significant, they are not shown in the tables. The percentages of the studied traits were transformed to arcsine values and then re-transformed to the original values after analysis. Mortality rate was analyzed by chi-square test. Results are given as means and pooled standard error of means. Differences between means were tested with Duncan's multiple range test at the level of $\alpha=$ 0.05 [17].

\section{RESULTS}

\section{Growth traits}

Live weight at 6th wk was not affected by feeding type and water temperature, but the live weight was significantly higher in IF chickens at the 5 th wk $(\mathrm{p}<0.05)$. Water temperature did not affect the average weekly gain. IF broiler chickens were higher compared to AL group in terms of average weekly gain at 4,5 , and 6 wk of age (Table 3 ).

Although feeding type did not affect feed intake in 4 th and 5 th wk, and it was higher in IF chickens at 6th wk $(\mathrm{p}<0.01)$. Although feed intake in chickens that consumed CW was high during the study, but this was not found significant. In addition, feeding type and CW implementation did not affect FCR and interactions also were not significant (Table 4).

Intermittent fed chickens consumed an average of 15.2 $\mathrm{mL}$ more water per day between 4 to 6 wk than AL chickens, 
Table 3. Effect of feeding type and water temperature on weekly live weight

\begin{tabular}{|c|c|c|c|c|c|c|c|}
\hline \multirow{2}{*}{ Treatments } & \multicolumn{4}{|c|}{ LW (g, week) } & \multicolumn{3}{|c|}{ AWG (g, week) } \\
\hline & 3 & 4 & 5 & 6 & 4 & 5 & 6 \\
\hline \multicolumn{8}{|l|}{ Feeding type } \\
\hline Ad-libitum & 879.1 & $1,508.9$ & $2,140.9$ & $2,672.0$ & 629.8 & $1,264.7$ & $1,790.1$ \\
\hline Intermittent & 887.5 & $1,559.5$ & $2,228.3$ & $2,772.7$ & 672.0 & $1,340.7$ & $1,883.4$ \\
\hline \multicolumn{8}{|l|}{ Water temp. } \\
\hline Normal & 893.0 & $1,544.5$ & $2,181.6$ & $2,724.4$ & 651.5 & $1,288.5$ & $1,831.3$ \\
\hline Cold & 875.3 & $1,528.3$ & $2,192.7$ & $2,726.3$ & 653.0 & $1,319.9$ & $1,846.9$ \\
\hline SEM & 7.21 & 14.81 & 21.74 & 27.13 & 8.59 & 15.51 & 22.01 \\
\hline \multicolumn{8}{|l|}{$p$-values } \\
\hline $\mathrm{FT}$ & 0.527 & 0.079 & 0.040 & 0.070 & 0.012 & 0.016 & 0.034 \\
\hline WT & 0.292 & 0.741 & 0.658 & 0.886 & 0.751 & 0.257 & 0.636 \\
\hline $\mathrm{FT} \times \mathrm{WT}$ & 0.085 & 0.212 & 0.570 & 0.617 & 0.479 & 0.988 & 0.244 \\
\hline
\end{tabular}

LW, live weight; AWG, average weekly gain; SEM, standard error of means; FT, feeding type; WT, water temperature.

Table 4. Effect of feeding type and water temperature on feed intake and feed conversion ratio

\begin{tabular}{|c|c|c|c|c|c|c|c|c|}
\hline \multirow{2}{*}{ Treatments } & \multicolumn{4}{|c|}{$\mathrm{FI}(\mathrm{g} / \mathrm{d}, \mathrm{wk})$} & \multicolumn{4}{|c|}{ FCR (g feed/g gain, wk) } \\
\hline & 4 & 5 & 6 & $4-6$ & 4 & 5 & 6 & $4-6$ \\
\hline \multicolumn{9}{|l|}{ Feeding type } \\
\hline Ad-libitum & 128.3 & 167.5 & 183.6 & 159.8 & 1.43 & 1.85 & 2.49 & 1.88 \\
\hline Intermittent & 131.9 & 171.7 & 193.3 & 165.6 & 1.38 & 1.87 & 2.52 & 1.86 \\
\hline \multicolumn{9}{|l|}{ Water temp. } \\
\hline Normal & 130.1 & 168.6 & 188.3 & 162.3 & 1.41 & 1.85 & 2.44 & 1.86 \\
\hline Cold & 130.4 & 170.8 & 189.2 & 163.5 & 1.40 & 1.80 & 2.56 & 1.88 \\
\hline SEM & 1.49 & 2.08 & 1.88 & 1.59 & 0.015 & 0.028 & 0.070 & 0.015 \\
\hline \multicolumn{9}{|l|}{$p$-values } \\
\hline $\mathrm{FT}$ & 0.249 & 0.288 & 0.008 & 0.075 & 0.089 & 0.501 & 0.458 & 0.707 \\
\hline WT & 0.828 & 0.522 & 0.629 & 0.593 & 0.672 & 0.370 & 0.421 & 0.646 \\
\hline $\mathrm{FT} \times \mathrm{WT}$ & 0.594 & 0.297 & 0.527 & 0.648 & 0.732 & 0.136 & 0.130 & 0.092 \\
\hline
\end{tabular}

$\mathrm{Fl}$, feed intake ( $\mathrm{g} / \mathrm{d}, \mathrm{wk}) ; \mathrm{FCR}$, feed conversion ratio ( $\mathrm{g}$ feed/g gain, wk); SEM, standard error of means; FT, feeding type; WT, water temperature.

however this was found to be insignificant $(\mathrm{p}>0.05)$. During the study, the water temperature did not affect water intake. The daily water intake of chickens consuming NW and CW was 377.0 and $377.2 \mathrm{~mL}$, respectively. Water intake/feed intake ratio did not change by the treatments, and similar intake occurred in all groups. During the study, water intake/feed intake ratio was found in the range of 2.30 to $2.31 \mathrm{~mL}$ for $1 \mathrm{~g}$ feed consumption in all groups (Table 5).

\section{Carcass traits}

Although the highest carcass weight was observed in IF chickens $(2,026.4 \mathrm{~g})$, the highest carcass yield was $77.2 \%$ in chickens that consumed CW; however these differences were insignificant. Water temperature had no significant effect on heart, liver, gizzard, and abdominal fat weights and percentages ( $\mathrm{p}>$ $0.05)$. There was no significant effect of water temperature on carcass part weights and ratios ( $>00.05)$. Thigh, breast, wing, back, and neck weights in IF chickens were higher than $\mathrm{AL}$, whereas all carcass part percentages were lower in chick- ens consuming CW, when compared to NW. However, no significant differences were found in terms of any traits (Tables $6,7)$.

\section{Rectal temperature and mortality}

While feeding type and water temperature did not affect the rectal temperature at 4 th and 6 th wk, significant differences were determined at 5 th $w \mathrm{k}$. IF increased rectal temperature at 5 wk of age compared to $\mathrm{AL}\left(41.1^{\circ} \mathrm{C}\right.$ vs $40.9^{\circ} \mathrm{C}$; $\left.\mathrm{p}<0.01\right)$. Rectal temperatures of chickens consuming CW and NW were different at the $5 \mathrm{wk}$ of age, and it was determined that CW decreased the body temperature (Table 8).

Higher mortality rate was observed in broiler chickens that consumed AL feed compared to IF (1.7\% vs $0.0 \%)$. Ad-libitum fed broiler chickens were followed by chickens that consumed $\mathrm{NW}(0.8 \%)$. However, none of these differences were significant ( $>0.05)$. There were no deaths in the other groups during the study (Table 8). 
Table 5. Effect of feeding type and water temperature on water intake

\begin{tabular}{|c|c|c|c|c|c|c|c|c|}
\hline \multirow{2}{*}{ Treatments } & \multicolumn{4}{|c|}{ WI (mL/d, wk) } & \multicolumn{4}{|c|}{ WI/FI (mL water/g feed, wk) } \\
\hline & 4 & 5 & 6 & $4-6$ & 4 & 5 & 6 & $4-6$ \\
\hline \multicolumn{9}{|l|}{ Feeding type } \\
\hline Ad-libitum & 280.2 & 379.9 & 450.8 & 370.3 & 2.18 & 2.27 & 2.46 & 2.30 \\
\hline Intermittent & 293.0 & 390.3 & 470.9 & 384.7 & 2.22 & 2.27 & 2.44 & 2.31 \\
\hline \multicolumn{9}{|l|}{ Water temp. } \\
\hline Normal & 286.7 & 386.6 & 463.4 & 378.9 & 2.20 & 2.29 & 2.46 & 2.32 \\
\hline Cold & 287.3 & 384.4 & 459.9 & 377.2 & 2.21 & 2.25 & 2.43 & 2.30 \\
\hline SEM & 4.77 & 6.68 & 7.00 & 5.50 & 0.02 & 0.02 & 0.03 & 0.02 \\
\hline \multicolumn{9}{|l|}{$p$-values } \\
\hline $\mathrm{FT}$ & 0.193 & 0.439 & 0.171 & 0.199 & 0.405 & 0.938 & 0.830 & 0.821 \\
\hline WT & 0.828 & 0.976 & 0.939 & 0.986 & 0.811 & 0.479 & 0.711 & 0.728 \\
\hline $\mathrm{FT} \times \mathrm{WT}$ & 0.370 & 0.350 & 0.421 & 0.320 & 0.348 & 0.687 & 0.195 & 0.324 \\
\hline
\end{tabular}

WI, water intake (mL/d, wk); WI/FI, water intake/feed intake (mL water/g feed, week); SEM, standard error of means; FT, feeding type; WT, water temperature.

Table 6. Effect of feeding type and water temperature on edible inner organs and abdominal fat

\begin{tabular}{|c|c|c|c|c|c|c|c|c|}
\hline \multirow{2}{*}{ Treatments } & \multirow{2}{*}{ SW (g) } & \multirow{2}{*}{$C W(g)$} & \multirow{2}{*}{ CDP $(\%)$} & \multirow{2}{*}{ Heart (\%) } & \multirow{2}{*}{ Liver (\%) } & \multirow{2}{*}{ Gizzard (\%) } & \multicolumn{2}{|c|}{ Abd. fat } \\
\hline & & & & & & & $\%^{11}$ & $\%^{2)}$ \\
\hline \multicolumn{9}{|l|}{ Feeding type } \\
\hline Ad-libitum & $2,528.8$ & $1,952.7$ & 77.0 & 0.64 & 2.74 & 1.21 & 2.60 & 2.09 \\
\hline Intermittent & $2,643.1$ & $2,026.4$ & 76.8 & 0.64 & 2.89 & 1.06 & 2.87 & 2.17 \\
\hline \multicolumn{9}{|l|}{ Water temp. } \\
\hline Normal & $2,548.3$ & $1,955.4$ & 76.6 & 0.63 & 2.90 & 1.16 & 2.80 & 2.13 \\
\hline Cold & $2,623.6$ & $2,023.8$ & 77.2 & 0.64 & 2.74 & 1.10 & 2.66 & 2.12 \\
\hline SEM & 56.87 & 45.58 & 0.28 & 0.02 & 0.09 & 0.05 & 0.19 & 0.14 \\
\hline \multicolumn{9}{|l|}{$p$-values } \\
\hline FT & 0.336 & 0.431 & 0.545 & 0.619 & 0.234 & 0.149 & 0.780 & 0.921 \\
\hline WT & 0.524 & 0.455 & 0.363 & 0.594 & 0.106 & 0.058 & 0.973 & 0.977 \\
\hline $\mathrm{FT} \times \mathrm{WT}$ & 0.854 & 0.699 & 0.188 & 0.083 & 0.228 & 0.129 & 0.995 & 0.854 \\
\hline
\end{tabular}

SW, slaughter weight; CW, cold carcass weight; CDP, cold carcass dressing percentage; SEM, standard error of means; FT, feeding type; WT, water temperature.

1) Percentage of abdominal fat to cold carcass weight.

2) Percentage of abdominal fat to slaughter weight.

Table 7. Effect of feeding type and water temperature on carcass parts

\begin{tabular}{lccccc}
\hline \multirow{2}{*}{ Treatments } & \multicolumn{5}{c}{ Percentages (\%) } \\
\cline { 2 - 6 } & Thigh & Breast & Wing & Back & Neck \\
\hline $\begin{array}{l}\text { Feeding type } \\
\text { Ad-libitum }\end{array}$ & 29.4 & 36.3 & 10.6 & 18.6 & 6.0 \\
$\quad \begin{array}{l}\text { Intermittent } \\
\text { Water temp. }\end{array}$ & 28.7 & 36.5 & 10.4 & 18.3 & 6.1 \\
$\quad$ Normal & 29.3 & 36.1 & 10.6 & 18.2 & 6.1 \\
Cold & 28.2 & 36.7 & 10.4 & 18.7 & 6.0 \\
$\quad$ SEM & 0.31 & 0.33 & 0.11 & 0.32 & 0.10 \\
p-values & & & & & \\
$\quad$ FT & 0.726 & 0.452 & 0.189 & 0.312 & 0.410 \\
WT & 0.726 & 0.528 & 0.229 & 0.804 & 0.766 \\
FT $\times$ WT & 0.227 & 0.592 & 0.563 & 0.312 & 0.099 \\
\hline
\end{tabular}

SEM, standard error of means; $F T$, feeding type; $W T$, water temperature.
Table 8. Effect of feeding type and water temperature on rectal temperature and mortality

\begin{tabular}{|c|c|c|c|c|}
\hline \multirow{2}{*}{ Treatments } & \multicolumn{3}{|c|}{ Rectal temperature $\left({ }^{\circ} \mathrm{C}\right.$, wk) } & \multirow{2}{*}{$\begin{array}{c}\text { Mortality } \\
(\%)\end{array}$} \\
\hline & 4 & 5 & 6 & \\
\hline \multicolumn{5}{|l|}{ Feeding type } \\
\hline Ad-libitum & 40.9 & 40.9 & 41.4 & 1.7 \\
\hline Intermittent & 40.9 & 41.1 & 41.1 & 0.0 \\
\hline \multicolumn{5}{|l|}{ Water temp. } \\
\hline Normal & 40.9 & 41.1 & 41.2 & 0.8 \\
\hline Cold & 40.9 & 40.9 & 41.2 & 0.4 \\
\hline SEM & 0.06 & 0.05 & 0.07 & 0.10 \\
\hline \multicolumn{5}{|l|}{ p-values } \\
\hline FT & 0.843 & 0.004 & 0.118 & 0.662 \\
\hline WT & 0.560 & 0.051 & 0.916 & 0.662 \\
\hline $\mathrm{FT} \times \mathrm{WT}$ & 0.079 & 0.375 & 0.787 & 0.552 \\
\hline
\end{tabular}

SEM, standard error of means; FT, feeding type; $\mathrm{WT}$, water temperature. 


\section{DISCUSSION}

High ambient temperatures in broiler production may cause various harmful effects on physiological, immune, welfare, health, performance, and meat quality and serious economic losses may occur [4]. IF chickens use their gizzard and crop to store their feed and maintain their efficiency and performance for extended periods [18]. In the present study, although the live weight of chickens fed intermittent was higher than the AL group at $5 \mathrm{wk}$ of age, this difference was found insignificant at the end of 6th wk. This result was contrary to [19]. Intermittent feeding did not significantly affect live weight gain [18-20]; however in our study, IF chickens gained more live weight compared to AL chickens at 4, 5, and 6 wk of age.

Water temperature may affect the feed, water intake and performance of broiler chickens, especially under hot environmental conditions. When the temperature of consumed water is lower than body temperature, it helps to keep the metabolic temperature lower and increases appetite for water and feed [14]. The CW intake was found to increase the slaughter weight and average weekly gain [12-21]. However, in our study, no significant difference was found between slaughtering weights of broilers consuming NW or CW.

IF and AL implementations did not significantly affect the average daily feed intake of broilers during 4 and $5 \mathrm{wk}$. However, feed intake was higher in the chickens fed intermittently in the 6th wk [22], and our findings are consistent with this result. Also, broilers fasted for a certain time had a greater tendency to consume feed [22]. Another important point was that this increase in feed intake occurred in the last week and also LW increased. This shows that the amount of feed that cannot be consumed during hot hours is compensated by consuming excessively during cool hours.

The FCR is improved in broiler chickens fed intermittently compared with ad-libitum feeding [23,24], however it was determined that there was no significant effect in our study. These results were in line with [25] and who reported that IF does not affect feed conversion ratio. This may be explained by the low tendency of the feed intake in AL groups due to high temperature between 11.00 to $17.00 \mathrm{~h}$. It is seen that there is no significant difference in feed intake between $\mathrm{AL}$ and IF chickens between 4 to $6 \mathrm{wk}$. Cold water intake did not affect feed intake of broilers [24], and similar results were found in our study. However, IF and CW improved FCR during hot hours [24], but these results inconsistent with the our findings.

Although water intake tended to be higher in IF chickens compared to AL, this difference was found insignificant. The water intake/feed intake ratio is 2.02 under normal environmental conditions [26]. However, since the ambient temperatures reached $30^{\circ} \mathrm{C}$, this rate increased to 2.30 to 2.31 in our study. Due to the increased ambient tempera- ture, there was an increase in water intake/feed intake ratio, and this increase was not the same as in all treatments. In accordance with our findings, water temperature did not affect amount of water intake [12]. However, there are also studies reporting that the amount of water intake increases as the water temperature increases [27].

The effect of feeding type and water temperature on carcass traits, edible inner organ and abdominal fat levels were insignificant and results were similar to [24]. However unlike our findings, the best carcass yield was determined in chickens fed intermittently for 4 hours [28]. IF increased carcass yield and internal organ ratios compared to AL chickens [29] and these findings were found to be inconsistent with our results. Besides, there are conflicting results between IF and abdominal fat levels. Abdominal fat levels increased as a result of IF [11], while it has been reported that it decreased [29]. However in our findings, the rate of abdominal fat did not change significantly among treatments. Also, it is considered that the similarity of the slaughtering weight did not affect carcass traits significantly. In parallel with this, there was no difference in carcass yield, edible inner organ, and abdominal fat levels.

The amount of breast and thigh meat are composed of $60 \%$ to $65 \%$ of the carcass. The proportion of carcass parts are mainly dependent on live weight. Some implementations such as IF reduced the amount of breast meat compared to chickens fed ad-libitum [30], but the similarity in live weight values in our study did not cause differences breast and thigh percentages among treatments. Consistent with our results, IF treatment in broiler chickens does not affect the percentage of breast, leg and wing [10]. Water temperature had no effect on percentage of carcass components except for the amount of wings, but that the amount of wings of the chickens that consumed CW was lower than drinking NW [12]. In our study, all other carcass parts including the amount of wings did not differ according to water temperature.

IF in broiler chickens helps to maintain performance by preventing excessive body temperature under heat stress conditions [24]. In our study, changes in the performance of IF chickens did not occur at the expected level compared with AL chickens. In terms of rectal temperature, the IF chickens were higher than AL chickens at 5 wk of age. While IF chickens are expected to have a lower body temperature [20-24], the temperature was significantly increased in our study. Rectal temperature and body weight at the 5th wk was also considerably higher in IF chickens. This can be explained by the increase in metabolic heat production with a significant increase in live weight in IF chickens, but the increase in body temperature as a result of poor heat dissipation due to hot ambient conditions. In the 6th wk, there was no difference between IF and AL chickens in terms of rectal temperatures, 
however some research results show that IF chickens had lower body temperature compared to AL $[31,32]$. The similarity of the rectal temperatures of IF and AL chickens in the 6th wk shows that these chickens can cope with heat stress and this does not make any difference in their performance. It is thought that the consumption of $\mathrm{CW}$ in the 5 th week may have prevented the increase in body temperature and this result was in line with [14]. Although CW consumption decreased to rectal temperature slightly $\left(0.2^{\circ} \mathrm{C}\right)$ compared with NW, but performance is not affected.. However, IF increased the body temperature by $0.2^{\circ} \mathrm{C}$, while $\mathrm{AL}$ increased by $0.5^{\circ} \mathrm{C}$ in chickens during the study. It may be said that IF implementation suppresses the sudden increase in body temperature under hot ambient temperatures.

Actual deaths were within acceptable limits (between 0\% to $1.7 \%$ ) and evaluated as normal. It was found that intermittent feed and CW applications did not affect the mortality rate [12-24].

As a result of the study, it was found that IF increased the average weekly weight gain in broiler chickens reared under daily heat stress for $6 \mathrm{~h}$ between 22 to $42 \mathrm{~d}$ of age. IF in hot environmental conditions slightly increased performance without adversely affecting health, welfare, and physiological traits, whereas CW implementation had no significant effect on performance. It may also be said that IF suppresses a sudden increase in body temperature depending on age and live weight.

\section{CONFLICT OF INTEREST}

We certify that there is no conflict of interest with any financial organization regarding the material discussed in the manuscript.

\section{ACKNOWLEDGMENTS}

Authors thank the technical and administrative staff working at "Eskişehir Geçit Kuşağı Agricultural Research Institute", where breeding and selection applications of the pure lines used in the production of "Anadolu- $T$ " broiler chickens were carried out. The study was supported by Ondokuz Mayis University Project Office (Project number: PYO.ZRT.1901.18.014).

\section{REFERENCES}

1. Sahin K, Sahin N, Kucuk O, Hayirili A, Prasad AS. Role of dietary zinc in heat stressed poultry: a review. Poult Sci 2009; 88:2176-83. https://doi.org/10.3382/ps.2008-00560

2. Azoulay Y, Druyan S, Yadgary L, Hadad Y, Cahaner A. The viability and performance under hot conditions of featherless broilers versus fully feathered broilers. Poult Sci 2011;90:1929. https://doi.org/10.3382/ps.2010-01044
3. Hu JY, Hester PY, Makagon MM, Xiong Y, Gates RS, Cheng HW. Effect of cooled perches on performance, plumage condition, and foot health of caged White Leghorn hens exposed to cyclic heat. Poult Sci 2019;98:2705-18. https://doi.org/10. 3382/ps/pez039

4. Hristov AK, Degaetano AT, Rotz CA, et al. Climate change effects on livestock in the Northeast US and strategies for adaptation. Clim Change 2018;146:33-45. https://doi.org/10. 1007/s10584-017-2023-z

5. Cahaner A, Deeb N, Gutman M. Effects of the plumagereducing naked neck $(\mathrm{Na})$ gene on the performance of fastgrowing broilers at normal and high ambient temperatures. Poult Sci 1993;72:767-75. https://doi.org/10.3382/ps.0720767

6. Park SO, Hwangbo J, Ryu CM, et al. Effects of extreme heat stress and continuous lighting on growth performance and blood lipid in broiler chickens. J Korean Appl Sci Technol 2013;30:78-87. https://doi.org/10.12925/jkocs.2013.30.1.078

7. Daghir N. Nutrition and climatic stress. In: Proceedings of the XXth World Poultry Congress WPSA; 1996: New-Delhi, India. pp. 141-50.

8. Sahraei M. Feed restriction in broiler chickens production: a review. Glob Vet 2012;8:449-58.

9. Bruno L, Maiorka A, Macari M, Furlan RL, Givisiez P. Water intake behavior of broiler chickens exposed to heat stress and drinking from bell or and nipple drinkers. Braz J Poult Sci 2011;13:147-52. https://doi.org/10.1590/S1516-635X2011 000200009

10.Özkan S, Akbaş Y, Altan Ö, Altan A, Ayhan V, Özkan K. The effect of short-term fasting on performance traits and rectal temperature of broilers during the summer season. Br Poult Sci 2003;44:88-95. https://doi.org/10.1080/00071660310000 85292

11.El-Sagheer M, Makled MN. Effect of duration of feed withdrawal versus ad libitum feeding during high environmental temperature on broiler chicken performance. Egypt Poult Sci J 2005;25:333-50.

12. Abioja M, Osinowo O, Smith O, Eruvbetine D, Abiona J. Evaluation of cold water and vitamin $\mathrm{C}$ on broiler growth during hot-dry season in SW Nigeria. Arch Zootec 2011;60:1095103.

13. Jones $F$, Watkins $S$. How does taste influence water consumption in broilers. Avian Advice 2009;11:8-11.

14. Fairchild B, Ritz C. Poultry drinking water primer. UGA Cooperative Extension Bulletin 1301. 2012.

15. Tůmová E, Chodová D, Härtlová $H$, Fučiková $A$, Ketta $M$. Effect of feeding regime on the performance and blood parameters of male and female broiler chickens. S Afr J Anim Sci 2019;49:244-52. https://doi.org/10.4314/sajas.v49i2.5

16. Yamak US, Sarica M, Boz MA. Comparing slow-growing chickens produced by two-and three-way crossings with commercial genotypes: 1 . Growth and carcass traits. Eur Poult Sci 2014;78. https://doi.org/10.1399/eps.2014.29 
17. Önder H. Nonparametric statistical methods used in biological experiments. BSJ Eng Sci 2018;1:1-6.

18. Aliakbarpour HR, Chamani M, Rahimi G, Sadeghi AA, Qujeq D. Intermittent feeding programme and addition of Bacillus subtilis based probiotics to the diet of growing broiler chickens: Influence on growth, hepatic enzymes and serum lipid metabolites profile. Arch Anim Breed 2013;56:410-22. https://doi. org/10.7482/0003-9438-56-040

19.Svihus B, Lund VB, Borjgen B, Bedford MR, Bakken M. Effect of intermittent feeding, structural components and phytase on performance and behaviour of broiler chickens. Br Poult Sci 2013;54:222-30. https://doi.org/10.1080/00071668.2013. 772952

20.Lozano C, De Basilio V, Oliveros I, et al. Is sequential feeding a suitable technique to compensate for the negative effects of a tropical climate in finishing broilers? Anim Res 2006;55: 71-6. https://doi.org/10.1051/animres:2005047

21. Farghly MFA, Abd El-Hack ME, Alagawany M, Saadeldin IM, Swelum AA. Wet feed and cold water as heat stress modulators in growing Muscovy ducklings. Poult Sci 2018;97:1588-94. https://doi.org/10.3382/ps/pey006

22. Mahmood S, Hassan S, Ahmed F, Ashraf M, Alam M, Muzaffar A. Influence of feed withdrawal for different durations on performance of broilers in summer. Int J Agric Biol 2005;7: 975-8.

23. Butzen FM, Ribeiro AM, Vieira MM, Kessler AM, Dadalt JC, Della MP. Early feed restriction in broilers. I-Performance, body fraction weights, and meat quality. J Appl Poult Res 2013;22:251-9. https://doi.org/10.3382/japr.2012-00639

24.Farghly MFA, Mahrose KM, Galal AE, et al. Implementation of different feed withdrawal times and water temperatures in managing turkeys during heat stress. Poult Sci 2018;97:307684. https://doi.org/10.3382/ps/pey173

25. Rambau MD, Mudau ML, Makhanya SD, Benyi K. Effects of stocking density and daily feed withdrawal periods on the performance of broiler chickens in a semi-arid environment. Trop Anim Health Prod 2016;48:1547-54. https://doi.org/10. 1007/s11250-016-1126-2

26. Williams CL, Tabler GT, Watkins SE. Comparison of broiler flock daily water consumption and water-to-feed ratios for flocks grown in 1991, 2000-2001, and 2010-2011. J Appl Poult Res 2013;22:934-41. https://doi.org/10.3382/japr.201300767

27.Puma MC, Xin H, Gates RS, Ahn DU. Effects of drinking water temperature on laying hens subjected to warm cyclic environmental conditions. In: Stowell RR, Bucklin R, Bottcher RW, editors. Livestock environment VI Proceedings of the 6th International Symposium; 2001 May 21-23: Louisville, Kentucky, USA. pp. 235-43.

28. Hamidu JA, Kyeiwaa V, Bobie-Ansah D, Brown CA, Atuahene CC, Adomako K. Optimizing feed withdrawal in broiler effect of feed withdrawal timing on broiler carcass yield in tropics. Am Res J Agric 2015;1:7-15.

29.De Silva PHGJ, Kalubowila A. Influence of feed withdrawal for three hour time period on growth performance and carcass parameters later stage of male broiler chickens. Iran J Appl Anim Sci 2012;2:191-7.

30. Boostani A, Ashayerizadeh A, Mahmoodian FHR, Kamalzadeh A. Comparison of the effects of several feed restriction periods to control ascites on performance, carcass characteristics and hematological indices of broiler chickens. Braz J Poult Sci 2010;12:170-7. https://doi.org/10.1590/S1516-635X201000 0300006

31. Farghly MFA. Changing lighting and feeding time to alleviate the deleterious effect of hot Assiut summer on performance of Japanese quail. Egypt J Anim Prod 2011;48:315-30.

32. Farghly MFA, Hassanien HHM. Effect of feed frequencies and durations on performance of broiler chicks. Egypt Poult Sci J 2012;32:273-88. 